\title{
Endoscopic submucosal dissection in Spain: Outcomes and development possibilities
}

\author{
Juan J. Vila ${ }^{1}$, Marcos Kutz², Gloria Fernández-Esparrach ${ }^{3}$, Leopoldo López-Rosés ${ }^{4}$, Sarbelio Rodríguez ${ }^{5}$ \\ and Andrés Sánchez-Yague ${ }^{6}$
}

\begin{abstract}
${ }^{1}$ Endoscopy Unit. Department of Gastroenterology. Complejo Hospitalario de Navarra. Pamplona. Spain. ${ }^{2}$ Department of Gastroenterology. Hospital de Zumárraga. Zumárraga, Guipúzcua. Spain. ${ }^{3}$ Endoscopy Unit. Department of Gastroenterology ICMDiM. Hospital Clínic. IDIBAPS. CIBEREHD. Universitat de Barcelona. Barcelona, Spain. ${ }^{4}$ Endoscopy Unit. Department of Gastroenterology. Hospital Lucus Augusti. Lugo, Spain. ${ }^{5}$ Endoscopy Unit. Department of Gastroenterology. Hospital 12 de Octubre. Madrid, Spain. ${ }^{6}$ Endoscopy Unit. Department of Gastroenterology. Hospital Costa del Sol. Málaga, Spain
\end{abstract}

\begin{abstract}
Endoscopic submucosal dissection (ESD) allows endoscopic, curative, en-bloc resection of superficial malignant or premalignant lesions. This procedure was conceived over 10 years ago in Japan, but has not experienced great expansion in Western countries for different reasons. This article reviews ESD indications and outcomes, and reflects on the reasons that prevent ESD from becoming common clinical practice in Western hospitals. Finally, recommendations on ESD training in our setting are made.
\end{abstract}

Key words: Endoscopic submucosal dissection. Early gastric cancer. Gastric neoplasms. Endoscopy. Learning curve.

\section{INTRODUCTION}

Endoscopic resection of early gastric cancer (EGC) was first accomplished in Japan in the early 1970s (1). Deyhle et al. had previously described in 1973 resection of sessile colonic polyps after submucosal saline injection. This maneuver produced lesion elevation and allowed its subsequent excision through snare electrocoagulation. The procedure represents the basis for the techniques known as "inject and cut" resections (2), which were followed by the introduction of endoscopic mucosal resection (EMR) with "injection, elevation and cut" (3) and strip-biopsy (4).

In 1988, Hirao excised a lesion by initially delimiting it with a circumferential incision and subsequently removing it with a snare, performing what is now known as the hybrid resection technique (5). In 1992, Inoue performed

Received: 11-03-2013

Accepted: 29-05-2013

Correspondence: Juan J. Vila. Endoscopy Unit. Department of Gastroenterology. Complejo Hospitalario de Navarra. c/ Irunlarrea, 3. 31008 Pamplona, Navarra. Spain

e-mail: juanjvila@gmail.com
EMR with a cap placed on the distal end of the endoscope (6), and in 1997, Akayima accomplished EMR using band ligation (7).

The hybrid resection technique described by Hirao (5) represented the starting point for the development of endoscopic submucosal dissection (ESD) procedures and finally, in 1999, Gotoda described the first resection according to the ESD technique (8), whose stages are summarized in figure 1.

ESD has since greatly expanded in Asian countries such as Japan and Korea, but this process has not occurred in Western countries like Spain.

The purpose of this article is to evaluate the reasons that account for this fact, as well as to make suggestions regarding the conditions that should be implemented in our country in order to introduce the practice of ESD. Before evaluation of these issues, indications and outcomes of ESD are reviewed.

\section{ESD INDICATIONS}

ESD indications in any anatomical segment are limited by two factors, namely the resectability of the lesion (a characteristic directly related with its size), and the risk of lymphatic invasion. The risk of lymph node metastases in EGC approaches $3 \%$, but increases to $20 \%$ when submucosal invasion in present (9). There are whatsoever small differences depending on the organ involved.

Absolute esophageal ESD indications accepted by the Japanese Esophagus Association include lesions with high

Vila JJ, Kutz M, Fernández-Esparrach G, López-Rosés L, Rodríguez S, Sánchez-Yague A. Endoscopic submucosal dissection in SPAIN: Outcomes and development possibilities. Rev Esp Enferm Dig 2013;105:544-552. 


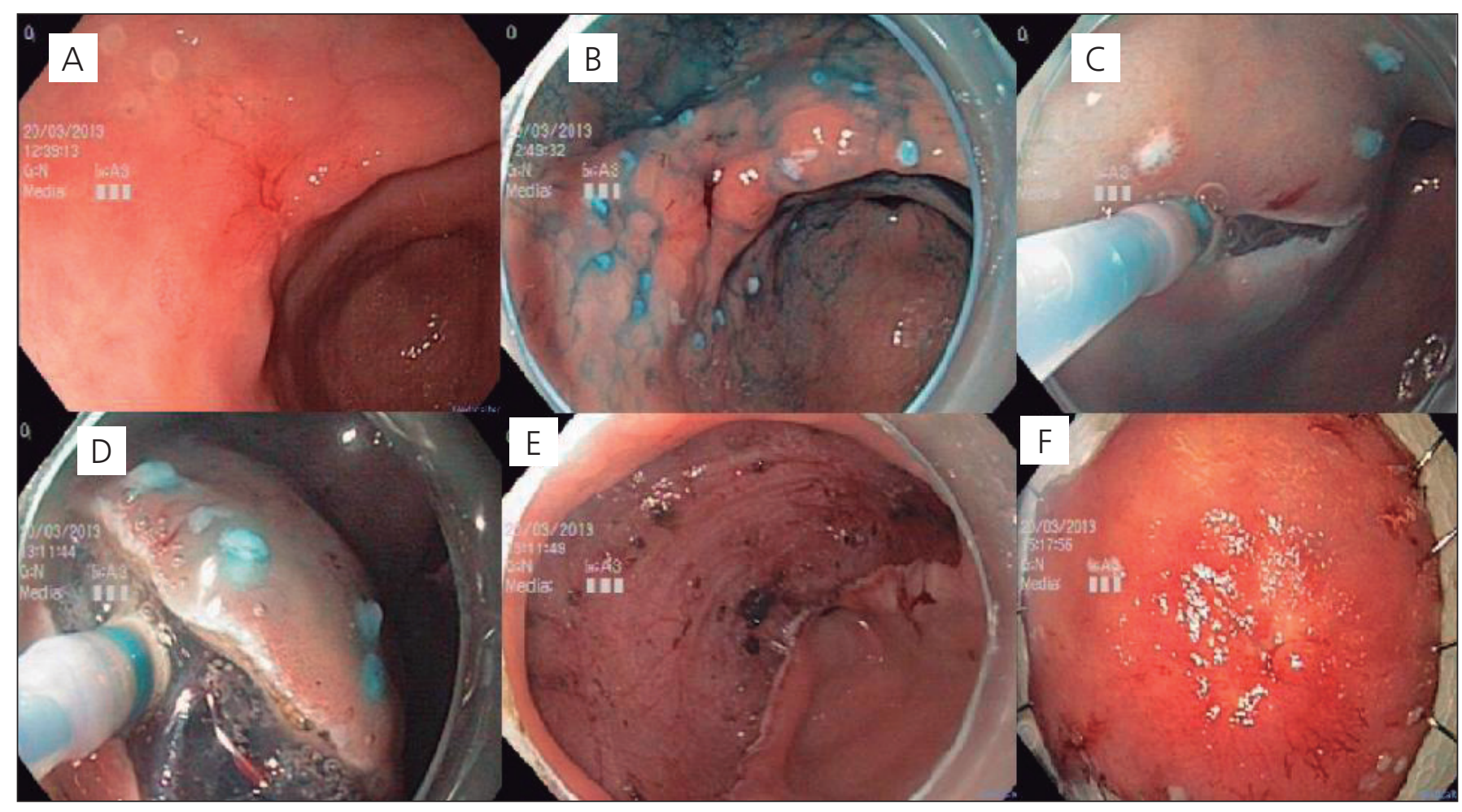

Fig. 1. The different stages of ESD are represented through this image, starting by probably the most important phase, which is early diagnosis. A. In the anterior portion of the incisura angularis a flat and depressed lesion is identified (Paris $\mathrm{ll} \mathrm{b}+\mathrm{c}$ ) and biopsied showing a well differentiated adenocarcinoma. B. ESD is indicated starting with marking the borders of the lesion. C. After glycerol submucosal injection the lesion is elevated and the circumferential cut external to the marking is accomplished. D. After exposure of the submucosal space with the glycerol and indigo carmin combination the submucosal dissection is performed. E. When the gastric lesion is completely excised, an adequate endoscopic hemostasis must be completed in prevention of delay ulcer bleeding. F. The specimen must be correctly pinned for histological analysis.

grade dysplasia or in situ carcinoma that do not surpass the lamina propria and are restricted to a maximum of two thirds of the circumference (10). The risk of nodal metastases in these circumstances is inexistent, as has been demonstrated in studies that analyzed a great number of surgical specimens with exhaustive investigation of lymphatic invasion $(11,12)$. Extended relative indications are also accepted for high surgical risk patients: Carcinomas with a submucosal invasion depth under $200 \mu \mathrm{m}$ (sm1), which entail a 10-15\% risk of lymphatic metastases, and lesions involving more than two thirds of the circumference.

It must be kept in mind that virtually all esophageal ESD experience has been developed on squamous carcinoma, because of the low incidence of adenocarcinoma in Asian countries. The incidence of adenocarcinoma on Barrett's esophagus is however greater in Western countries, and this may represent an important field of ESD application in our context. Because this lesion has been scarcely studied in Japanese series, the previously described absolute ESD indications (13) must be carefully followed when considering ESD therapy for esophageal adenocarcinoma.

The standard gastric ESD indication is the resection of well-differentiated intestinal-type adenocarcinoma that is confined to the mucosa and lacks lymphovascular invasion. The neoplasm must be under $20 \mathrm{~mm}$ in diameter or under $10 \mathrm{~mm}$ when classified as a flat or depressed lesion (Paris 0-IIb or 0-IIc) (14).

Gotoda et al. proved these criteria to be overly restrictive, as they implied unnecessary surgical therapy for many patients. After analyzing a database with over 5,000 patients who had undergone gastrectomy and R2 lymphatic dissection, they were able to determine with high certainty the risk of node metastases in additional patient groups (15) (Table I), and consequently defined the expanded ESD indications, which include well-differentiated, non ulcerated mucosal adenocarcinomas of any size, ulcerated adenocarcinomas under $30 \mathrm{~mm}$ in diameter and those with submucosal invasion less than $500 \mu \mathrm{m}$ as long as they do not exceed $30 \mathrm{~mm}$ in diameter and lack lymphovascular invasion (16).

Colorectal ESD is recommended for lesions in which the probability of achieving en bloc resection with a polypectomy snare is low: Polyps with non granular lateral growth (LST-NG), particularly of the pseudo-depressed type; lesions with type VI cryptal pattern and protruded lesions suspected to correspond with carcinoma; fibrotic lesions; sporadic lesions detected in the context of chronic 
inflammatory diseases such as ulcerative colitis; and non disseminated carcinoma that was not successfully removed after endoscopic mucosal resection (17). Regarding malignant lesions, mucosal neoplasms or carcinomas with superficial $(<1,000 \mu \mathrm{m})$ submucosal invasion without lymphovascular invasion are amenable to ESD as well $(18,19)$.

\section{ESD OUTCOMES}

The outcomes from the main esophageal, gastric and colorectal ESD series are presented in Tables II, III and IV respectively. Taken together, the data describe an en bloc resection rate for esophagogastric lesions of over $95 \%$, and near $90 \%$ for colorectal lesions. R0 resection, understood as en bloc resection with tumor-negative resection margins, is achieved in up to $91 \%$ of esophageal lesions, $88 \%$ of gastric lesions and $78 \%$ of colonic and rectal lesions. These results are comparable to the ones described in surgical series. The recurrence rate is very low (around $1 \%$ ).

ESD permits complete en bloc resections, which warrant the histological examination of the whole specimen in a reliable way. The completeness of the resection can thus be evaluated, determining if further endoscopic or surgical treatment is required.

ESD therefore represents a safe and curative endoscopic procedure for superficial gastrointestinal lesions with the appropriate histological characteristics.

The most common ESD complication is gastrointestinal bleeding, which may occur in up to $20 \%$ of the cases. Risk factors for bleeding include chronic renal impairment, hepatic cirrhosis and subtotal gastrectomy (20). The incidence of bleeding is higher in gastric ESD, and the risk increases along with lesion size $(>31 \mathrm{~mm})$. Neoplasms located in the proximal two thirds of the stomach entail also a higher risk (21). Delayed bleeding taking place 24 hours after the performance of ESD can occur in up to $6 \%$ of the cases, and may be severe (22). It should be kept in mind that bleeding is in fact inherent to the procedure, for submucosal vessels must be cut. Bleeding should be expected and adequately managed.

The second most common ESD complication is perforation, which occurred in around $5 \%$ of the cases in most studies, but reached $20 \%$ in some series (23). Over $90 \%$ of such complications can be managed endoscopically (20).

Pneumotorax is a rare complication that may befall in esophageal, gastroesophageal junction and gastric fundus

Table I. Definition of EGC groups with non-existent risk of lymphatic invasion (expanded criteria) by Gotoda et al. (15)

\begin{tabular}{|c|c|c|c|}
\hline Criteria & $n$ & $\begin{array}{l}\text { Incidence of } \\
\text { lymphatic invasion }\end{array}$ & IC $95 \%$ \\
\hline $\begin{array}{l}\text { Well differentiated mucosal adenocarcinoma, absence of lymphovascular invasion, less than } \\
30 \mathrm{~mm} \text { in diameter, regardless of ulceration }\end{array}$ & 1,230 & $0 / 1,230 ; 0 \%$ & $0-0.3 \%$ \\
\hline $\begin{array}{l}\text { Well differentiated intramucosal adenocarcinoma, absence of lymphovascular invasion, absence } \\
\text { of ulceration, regardless of size }\end{array}$ & 929 & 0/929; 0 \% & $0-0.4 \%$ \\
\hline $\begin{array}{l}\text { Undifferentiated mucosal cancer, absence of lymphovascular invasion, absence of ulceration, } \\
\text { less than } 20 \mathrm{~mm} \text { in diameter }\end{array}$ & 141 & $0 / 141 ; 0 \%$ & $0-2.6 \%$ \\
\hline $\begin{array}{l}\text { Well differentiated adenocarcinoma less than } 30 \mathrm{~mm} \text { in diameter confined to the upper } 0.5 \mu \mathrm{m} \\
(\mathrm{sm} 1) \text { of the submucosa without lymphovascular invasion }\end{array}$ & 145 & $0 / 145 ; 0 \%$ & $0-2.5 \%$ \\
\hline
\end{tabular}

Table II. Outcomes of the most relevant series published in English whose goal was to evaluate clinical outcomes of esophageal ESD performed on superficial lesions

\begin{tabular}{|c|c|c|c|c|c|c|c|}
\hline Author & Lesions & En bloc & RO & Bleeding & Perforation & Stenosis & Recurrence \\
\hline Oyama 2005 (57) & 102 & $95 \%$ & --- & --- & $0 \%$ & $7 \%$ & 0 \\
\hline Fujishiro 2006 (58) & 58 & $100 \%$ & $78 \%$ & $0 \%$ & $6.9 \%$ & $16 \%$ & $4.5 \%$ \\
\hline Ono 2009 (60) & 107 & $100 \%$ & $88 \%$ & $0 \%$ & $3.7 \%$ & $18 \%$ & $0.9 \%$ \\
\hline Nonaka 2010 (61) & 27 & $100 \%$ & $88.9 \%$ & $0 \%$ & $3.7 \%$ & $11 \%$ & $0 \%$ \\
\hline Repici 2010 (63) & 20 & $90 \%$ & $90 \%$ & $0 \%$ & $0 \%$ & $5 \%$ & $0 \%$ \\
\hline Ishii 2010 (64) & 37 & $100 \%$ & $95 \%$ & $0 \%$ & $0 \%$ & $24 \%$ & $0 \%$ \\
\hline Yamashina 2012 (65) & 39 & $100 \%$ & $92 \%$ & $0 \%$ & $2.5 \%$ & $28 \%$ & --- \\
\hline Yamamoto 2012 (66) & 90 & $98.9 \%$ & $86.7 \%$ & $1.1 \%$ & $3.3 \%$ & $18.9 \%$ & $0 \%$ \\
\hline Toyonaga 2012 (67) & 138 & --- & $95.7 \%$ & $0 \%$ & $0 \%$ & $0 \%$ & $0 \%$ \\
\hline
\end{tabular}


Table III. Outcomes of the most relevant series of gastric ESD

\begin{tabular}{lcccccc}
\hline Author & Lesions & En bloc & RO & Bleeding & Perforation & Recurrence \\
\hline Oda 2005 (21) & 1,033 & $98 \%$ & $93 \%$ & $13 \%$ & $4 \%$ & -- \\
Oka 2006 (68) & 195 & $83.1 \%$ & $83.1 \%$ & $6.2 \%$ & $8.7 \%$ & $0 \%$ \\
Watanabe 2006 (69) & 120 & $91.7 \%$ & $87.5 \%$ & --- & $4.2 \%$ & -- \\
Takenaka 2008 (70) & 306 & $92 \%$ & $80.4 \%$ & $0.65 \%$ & $5.2 \%$ & $2.2 \%$ \\
Goto 2009 (71) & 276 & $96.7 \%$ & $91.7 \%$ & --- & --- & $0.9 \%$ \\
Isomoto 2009 (72) & 589 & $94.9 \%$ & --- & $1.8 \%$ & $4.5 \%$ & $0.8 \%$ \\
Nakamoto 2009 (73) & 202 & $94.3 \%$ & $92.6 \%$ & $1.6 \%$ & $2.5 \%$ & $0 \%$ \\
Hotta 2010 (74)* & 318 & --- & $87 \%$ & $0.63 \%$ & $4.7 \%$ & -- \\
Hotta 2010 (74)** & 385 & --- & $89 \%$ & $0.26 \%$ & $3.6 \%$ & -- \\
Abe 2011 (75) & 470 & --- & $77.9 \%$ & $3.2 \%$ & $2.8 \%$ & $0.7 \%$ \\
Akasaka 2011 (76) & 1,188 & $95.3 \%$ & --- & $3.1 \%$ & $4.1 \%$ & -- \\
Yamamoto 2012 (66) & 670 & $98.8 \%$ & $92.4 \%$ & $5.9 \%$ & $2.5 \%$ & $0.75 \%$ \\
Toyonaga 2012 (67) & 1,136 & --- & $97.1 \%$ & $3.6 \%$ & $1.8 \%$ & $0 \%$ \\
Schumacher 2012 (77) & 29 & $90 \%$ & $64.3 \%$ & $3.45 \%$ & $0 \%$ & --- \\
\hline
\end{tabular}

*Low volume centers. **High volume centers.

Table IV. Outcomes of the most relevant series of colorectal ESD

\begin{tabular}{|c|c|c|c|c|c|c|}
\hline Author & Lesions & En bloc & RO & Bleeding & Perforation & Perforation \\
\hline Niimi 2010 (78) & 310 & $90.3 \%$ & $74.5 \%$ & $1.6 \%$ & $4.8 \%$ & $2 \%$ \\
\hline Nishiyama 2010 (79) & 300 & $89.2 \%$ & $79.1 \%$ & $0.7 \%$ & $8.1 \%$ & $0.3 \%$ \\
\hline Yoshida 2010 (81)* & 87 & $93 \%$ & --- & $2.2 \%$ & $9.1 \%$ & --- \\
\hline Yoshida $2010(81)^{\star *}$ & 32 & $81.2 \%$ & --- & 0 & $3.1 \%$ & --- \\
\hline Yamamoto 2012 (66) & 467 & $91.3 \%$ & $80.4 \%$ & $1.3 \%$ & $4.3 \%$ & $1.2 \%$ \\
\hline Toyonaga 2012 (67) & 361 & --- & $98.3 \%$ & $1.7 \%$ & $1.9 \%$ & $0 \%$ \\
\hline
\end{tabular}

*Patients younger than 75 years. **Patients older than 75 years.

ESD (20), and requires procedure cancellation, as it is a life threatening event.

\section{ESD VERSUS ALTERNATIVE THERAPIES}

ESD achieves significantly higher en bloc resection rates when performed on gastric ( 83 vs. $42 \%$ ) and colorectal (83.5-98.9 vs. 42.9-83.3 \%) lesions compared with EMR. It achieves superior R0 resection rates (83 vs. $24 \%)$ and lower recurrence rates on gastric (4 vs. $18 \%)$ and colorectal (0.2-2.3 vs. 1.4-25.9\%) lesions as well. On the other hand, ESD produces a higher proportion of gastric (2.8-20 $v s .<1 \%)$ and colorectal $(3.3-8 v$ v. $2.9 \%)$ perforations, and also a higher percentage of bleeding in both locations (22 vs. $10 \%$ and 1.7-2.4 vs. $1.4-2.9 \%$ respectively) (24-27).

Compared with surgery, ESD obtains similar 5-year survival rates (81-98\% depending on the location $v s .>$ $90 \%$ respectively). Recurrence rates are likewise compa- rable (1-14 \% in surgical series, 1-10\% in ESD series). However, morbidity and mortality are lower in ESD series (5-22 \% and $0-2 \%$ respectively) than in surgical series (12-80\% and $1-22 \%$ respectively).

Although thus far not thoroughly evaluated in published studies, ESD could entail an improved outcome in quality of life. Patients undergoing oncological surgical treatment do not relate complete recovery until 12 to 24 months after the procedure, and do not regain previous quality of life until 5 years after surgery (28-30). Patients deceased during the first two years after the operation are never able to recover their previous quality of life (28-30).

\section{DIFFUSION OF ESD IN SPAIN AND WESTERN COUNTRIES}

Nevertheless, the advantages listed above, ESD has not experienced such broad diffusion in Western countries as 
in Asian ones because of different reasons $(31,32)$ : a) ESD technology can be still considered undeveloped; b) it is restricted to expert hands and is not standardized; c) it is a challenging technique that implies a long learning curve, which consumes large amounts of time and is not without a high risk of complication; and d) it requires hospital admittance.

Considering that alternative minimally invasive surgical therapies entail very low morbidity and mortality, the slow pace of ESD introduction may be understood.

ESD difficulty is not only technical, as there are various factors that may increase it. The location of the lesion plays an important role, being distal gastric lesions the most amenable to resection, followed by rectal, proximal gastric, esophageal and colonic lesions. Duodenal lesions are considered the most demanding.

In addition, the location of the lesion within an organ has an influence on difficulty. Posterior wall lesions are harder to resect, as they hinder taking advantage of gravity while performing ESD.

A lesion diameter over $30 \mathrm{~mm}$ and the presence of submucosal fibrosis are two factors that may increase ESD difficulty as well (33).

Another factor that hampers the introduction of ESD in Western countries is a lower incidence of gastric cancer, which makes more difficult acquiring clinical expertise in EGC, the most adequate lesion to begin ESD training. Annual, age adjusted gastric cancer incidence in Japan is 60-70 cases per 100.000 inhabitants, while in Spain male incidence is 25 cases per 100,000 inhabitants, although it varies from central Spain to coastal regions. For instance, in Castilla León an incidence of 44 cases per 100,000 inhabitants has been described $(34,35)$.

Moreover, gastric cancer is diagnosed at an EGC stage in less than $20 \%$ of the cases in our country, while in Japan that figure reaches $53 \%(35,36)$. Screening programs that facilitate diagnosis in early stages have been introduced in the latter country, but the great difference between both figures still reveals that the strategy to diagnose EGC in our country must be improved. The completion of a training period at a leading institution in the diagnosis and treatment of EGC has been demonstrated effective in Japan as well as in our country $(37,38)$.

Because of all these reasons, many Western authors believe that ESD will not become universally introduced in Western countries unless progress in its efficiency is achieved and a means of performing it on outpatients is found (31).

On the other hand, the fact that as experience and expertise in ESD is obtained, procedure length and complications diminish significantly (39), is encouraging. A recent European series that included 91 gastric lesions excised through ESD described procedure duration of $153 \mathrm{~min}$ utes for the first 49 lesions, which averaged $36.4 \mathrm{~mm}$ in diameter. The next 42 lesions, with a diameter of $46.7 \mathrm{~mm}$ in average, required 161 minutes in average for their removal (40), a figure that does not significantly differ from the previous one despite the considerable increase in size. The development of new instruments and novel approaches should as well decrease ESD difficulty and morbidity (41-46).

Several Spanish groups have published their experience in ESD in an experimental level (44,47-49), while some of them have begun its application on clinical practice. The Vázquez-Sequeiros et al. (47) study described the performance of 6 ESD in a porcine ex-vivo model, followed by another 6 in a living porcine model, and a successful subsequent ESD in a patient with a $3 \mathrm{~cm}$ antral lesion.

Parra-Blanco et al. (49) suggested an experimental training model for our country that begins with the observation of procedures performed by experts, followed by training in an ex-vivo animal model, and lastly in a living animal model. Their work described the performance of eleven ESD in each animal model, and they verified that the time required to fulfill ESD in a living model is significantly less than that required to carry out the procedure in an ex-vivo model with a lesion of similar size. This suggests an adequate attainment of skills through the first stage of training. In the discussion of the article the author declares having acquired clinical experience in 5 gastric and one rectal ESD.

A 31 case ESD series performed over a 4 year period has been recently published (50). The average size of the lesions included was $36+/-17 \mathrm{~mm} ; 23$ of them were located in the rectum and sigmoid colon, one in the esophagus and 7 in the stomach. En bloc excision was achieved in 13 cases ( $42 \%$ ), and $\mathrm{R} 0$ resection was observed in 7 lesions $(22.6 \%)$. The incidence of perforation and bleeding was $16 \%$ and $26 \%$ respectively, while recurrence occurred in $9 \%$ of the cases. Adequate completion of resection through subsequent endoscopic therapy was achieved in all of them.

Although to the date still evidently scarce, a growing number of hospitals in our country is gathering experience in ESD. In fact, to our knowledge ESD has been applied in clinical practice in at least 12 Spanish hospitals.

\section{ESD TRAINING}

The ESD learning curve is long and complicated (51), and is approached differently in Asian and Western countries. In Japan, a sufficient general medicine training to correctly manage patients clinically is required to start instruction, as well as standard endoscopic skills. These skills include the ability to perform routine endoscopy using high definition endoscopes, to detect and characterize mucosal lesions, obtain biopsies, reach the cecum easily, and to master endoscopic hemostatic techniques, polypectomy and EMR (52).

However, the most valued virtues in a candidate to ESD training regard his or her attitude, as personality and character may affect his/her progress (52). For that reason, 


\section{Table V. European ESD position statement from} a panel of experts (55)

\begin{tabular}{l} 
Institutional requirements \\
Good quality imaging \\
Experienced histopathologist following the Japanese criteria \\
(adequate handling, attachment of the specimen with pins \\
on a frame, 2 mm sections, micrometric invasion, vessel and \\
lymphatic infiltration, etc.) \\
Dedicated endoscopic follow-up \\
Surgical and ITU therapy available \\
Availability of multidisciplinary management and decision \\
making \\
Minimum endoscopic training requirements \\
Adequate management of complications: Bleeding and \\
perforation \\
Hands-on experience in a model of isolated pig stomach and in \\
live pigs: At least 5 ESD procedures \\
Knowledge in indications and instruments \\
Exposure to experts: Observation of at least 15 ESD performed \\
by an expert, stays at reference institutions \\
Lesion requirements \\
Step-up approach, starting with lesions presenting in the \\
rectum or in the distal stomach, then colon, proximal stomach, \\
and finally in the esophagus \\
\hline
\end{tabular}

Japanese experts believe that not every endoscopist may be eligible to perform ESD (52).

Requirements for an endoscopist in training to start performing the procedure in clinical practice include gathering enough theoretical knowledge, experience and endoscopic skills to grant self-sufficiency. He/she should be able to assess the difficulty of a lesion and refer those that surpass his level of expertise to more experienced endoscopists. $\mathrm{He} /$ she should be capable of completing ESD on gastric lesions smaller than $2 \mathrm{~cm}$ without ulceration in less than 2 hours, and of achieving over $90 \%$ of curative resections with an incidence of complications under $3 \%$ (52).

In addition to all this, a competent endoscopist should be familiar with all available instruments, as well as with diathermy settings, which vary for each ESD stage depending on lesion location.

Finally, the Japanese training process requires an endoscopist to master gastric ESD before attempting the technique in other locations.

These general recommendations are applied in each institution by means of organized learning programs. In the National Cancer Center in Tokyo, ESD trainees are instructed in several stages. They initially obtain basic notions that permit detection and diagnosis of EGC, as well as ESD indications (53). In a second stage they observe multiple procedures performed by experts. In a later phase, they prepare and provide instruments to the endoscopist during the procedures, and acquire experience in animal models, where they are expected to complete at least 30 ESD. This phase may extend itself for a year (54). Even- tually they begin performing supervised ESD in clinical practice.

Distal, small EGCs without ulceration or fibrosis are targeted first. Thirty ESD must be completed in that location. Lesions in the proximal two thirds of the stomach are resected subsequently, and 40 such procedures must be accomplished.

An endoscopist is considered competent at colon ESD when he/she has fulfilled 40 procedures in that location.

This training program has demonstrated an excellent capability of rendering self-sufficient trainees who achieve complete resection rates of $100 \%$ and $1.7 \%$ complication rates (53).

In Western countries the learning curve is approached in a different manner, determined by the circumstances in those nations. In 2008, a board of European experts assisted by Japanese specialists gathered in Rotterdam developed a number of recommendations for the training and performance of ESD (55) (Table V).

Concerning the endoscopy unit, the use of high definition sets is endorsed (55). From our point of view, not only the quality of the image is important, but also the capability of the endoscope to provide adequate angulations that will permit its appropriate location facing the lesion and thus the correct performance of the technique. It is as well advisable to perform ESD with an endoscope equipped with an additional water channel.

Logistics concerning ESD must also be considered. A completely available endoscopy room and endoscopy assisting team, for whatever time is required, are necessary, and the room's schedule must be thus adapted to the requirements of each case. In some cases, the entire working day of an endoscopy room will have to be booked for an ESD procedure.

With regard to clinical practice, and as opposed to Japanese recommendations, it is advised in the West to commence with rectal or distal gastric lesions, followed by colonic lesions, proximal gastric lesions, and finally esophageal lesions (55). It is also considered imperative performing at least 10-20 ESD per year (55).

No consensus was however reached by this board regarding whether this technique should be performed exclusively in reference centers, as some Europeans authors endorse (56).

In our opinion, and although the organization of the health system in our country prevents from restricting the procedure to certain hospitals, it is essential that endoscopists willing to perform ESD complete an adequate training program. Observing at least 15 dissections performed by an expert at his accustomed working environment, which implies visiting reference centers, is highly recommendable when beginning the learning curve. Acquiring enough experience on animal models before progressing to clinical practice is likewise basic. Completing 30 supervised procedures in animal models is difficult to achieve in our environment, but, to our judgment, the requisite of 
only 5 procedures established by European experts (55) is too scarce. It is as well highly advisable that endoscopists performing ESD in our environment carry on with experimental practice in living animal or ex-vivo models, despite having initiated ESD application in clinical practice. This activity helps to maintain the necessary technical skills regardless of encountering a low number of ESD resectable lesions in their practice. If this recommendation were to be followed, permanent access to an experimental laboratory where these procedures could be carried out should be granted to endoscopists who perform ESD.

Once experimental practice has been acquired, following the previously mentioned expert recommendations in clinical practice is advisable. A progressive approach to each group of lesions as experience is gathered must be carried out. The progression should be based on the difficulty of lesions, as determined by their location and characteristics. Disregarding this recommendation may lead to severe complications (23) with detrimental consequences for patients as well as for the technique and the endoscopist.

In summary, ESD is an endoscopic technique that permits curative treatment of pre-malignant and superficial malignant lesions in the gastrointestinal tract, yet technically demanding and with a high risk of complication. These features, combined with a series of limitations, account for its slow diffusion in our health system and imply that it should be initially restricted to a small number of institutions and endoscopists. Several prerequisites should be fulfilled before the application of the technique is generalized in clinical practice. In the first place, the diagnostic rate of EGC should be improved by performing esophagogastroduodenoscopy with higher standards. In the second place, adequate training must be obtained, following the recommendations issued by Japanese and Western experts.

\section{REFERENCES}

1. Gotoda T, Yamamoto H, Soetikno RM. Endoscopic submucosal dissection of early gastric cancer. J Gastroenterol 2006;41:929-42.

2. Deyhle P, Largiader F, Jenny P. A method for endoscopic electroresection of sessile colonic polyps. Endoscopy 1973;5:38-40.

3. Martin TR, Onstad GR, Silvis SE, Vennes JA. Lift and cut biopsy technique for submucosal sampling. Gastrointest Endosc 1976;23:29-30.

4. Tada M, Shimada M, Murakami F, Mizumachi M, Arima K, Yanai $\mathrm{H}$, et al. Development of strip-off biopsy (in Japanese with English abstract). Gastroenterol Endosc 1984;26:833-9.

5. Hirao M, Masuda K, Asanuma T, Naka H, Noda K, Matsuura K, et al. Endoscopic resection of early gastric cancer and other tumors with local injection of hypertonic saline-epinephrine. Gastrointest Endosc 1988;34:264-9.

6. Inoue H, Endo M, Takeshita K, Yoshino K, Muraoka Y, Yoneshima $\mathrm{H}$. A new simplified technique of endoscopic esophageal mucosal resection using a cap-fitted panendoscope (EMRC). Surg Endosc 1992;6:264-5

7. Akiyama M, Ota M, Nakajima H, Yamagata K, Munakata A. Endoscopic mucosal resection of gastric neoplasms using a ligating device. Gastrointest Endosc 1997;45:182-6.
8. Gotoda T, Kondo H, Ono H, Saito Y, Yamaguchi H, Saito D, et al. A new endoscopic mucosal resection procedure using an insulationtipped electrosurgical knife for rectal flat lesions: Report of two cases. Gastrointest Endosc 1999;50:560-3.

9. Sano T, Kobori O, Muto T. Lymph node metastasis from early gastric cancer: Endoscopic resection of tumour. Br J Surg 1992;79:241-4.

10. Kuwano $\mathrm{H}$ et al. Guidelines for diagnosis and treatment of carcinoma of the esophagus. April 207 edition: Part I edited by the Japan Esophageal Society. Esophagus 2008;5:61-73.

11. Natsugoe S, Baba M, Yoshinaka H, Kijima F, Shimada M, Shirao K, et al. Mucosal squamous cell carcinoma of the esophagus: A clinicopathologic study of 30 cases. Oncology 1998;55:235-41.

12. Tajima Y, Nakanishi Y, Ochiai A, Tachimori Y, Kato H, Watanabe H, et al. Histopathologic findings predicting lymph node metastasis and prognosis of patients with superficial esophageal carcinoma: Analysis of 240 surgically resected tumors. Cancer 2000;88:1285-93.

13. Nicolás-Pérez D. Endoscopic submucosal dissection: Only for expert endoscopists? Gastroenterol Hepatol 2012;35:344-67.

14. Japanese Gastric Cancer Association. Japanese Classification of Gastric Carcinoma. 2nd English edition. Gastric Cancer 1998;1:10-24.

15. Gotoda T, Yanagisawa A, Sasako M, Ono H, Nakanishi Y, Shimoda T, et al. Incidence of lymph node metastasis from early gastric cancer: Estimation with a large number of cases at two large centers. Gastric Cancer 2000;3:219-25.

16. Japanese Gastric Cancer Association. Japanese classification of gastric carcinoma: 3rd English edition. Gastric Cancer 2011;14:101-12.

17. Tanaka S, Oka S, Chayama K. Colorectal endoscopic submucosal dissection: Present status and future perspective, including its differentiation from endoscopic mucosal resection. J Gastroenterol 2008;43:641-51.

18. Uraoka T, Saito Y, Matsuda T, Ikehara H, Gotoda T, Saito D, et al Endoscopic indications for endoscopic mucosal resection of laterally spreading tumours in the colorectum. Gut 2006;55:1592-7.

19. Huang C, Huang RX, Xiang P, Qiu ZJ. Current research status of endoscopic submucosal dissection for colorectal neoplasms. Clin Invest Med 2012;35:E158-64.

20. Kim YJ, Park DK. Management of complications following endoscopic submucosal dissection for gastric cancer. World J Gastrointest Endosc 2011;3:67-70.

21. Oda I, Gotoda T, Hamanaka H, Eguchi T, Saito Y, Matsuda T, et al. Endoscopic submucosal dissection for early gastric cancer: Technical feasibility, operation time and complications from large consecutive series. Dig Endosc 2005; 17:54-8.

22. Okada K, Yamamoto Y, Kasuga A, Omae M, Kubota M, Hirasawa T, et al. Risk factors for delayed bleeding after endoscopic submucosal dissection for gastric neoplasm. Surg Endosc 2011;25:98-107.

23. Coda S, Trentino P, Antonellis F, Porowska B, Gossetti F, Ruberto $\mathrm{F}$, et al. A Western single-center experience with endoscopic submucosal dissection for early gastrointestinal cancers. Gastric Cancer 2010;13:258-63.

24. Tajika M, Niwa Y, Bhatia V, Kondo S, Tanaka T, Mizuno N, et al. Comparison of endoscopic submucosal dissection and endoscopic mucosal resection for large colorectal tumors. Eur J Gastroenterol Hepatol 2011;23:1042-9.

25. Lee EJ, Lee JB, Lee SH, Kim DS, Lee DH, Lee DS, et al. Endoscopic submucosal dissection for colorectal tumors-1,000 colorectal ESD cases: one specialized institute's experiences. Surg Endosc 2013;27:31-9.

26. Oka S, Tanaka S, Kanao H, Ishikawa H, Watanabe T, Igarashi M, et al. Current status in the occurrence of postoperative bleeding, perforation and residual/local recurrence during colonoscopic treatment in Japan. Dig Endosc 2010;22:376-80.

27. Lian J, Chen S, Zhang Y, Qiu F. A meta-analysis of endoscopic submucosal dissection and EMR for early gastric cancer. Gastrointest Endosc 2012;76:763-70.

28. Kim AR, Cho J, Hsu YJ, Choi MG, Noh JH, Sohn TS, et al. Changes of quality of life in gastric cancer patients after curative resection: a longitudinal cohort study in Korea. Ann Surg 2012;256:1008-13.

29. Zeng J, Liu JS. Quality of life after three kinds of esophagectomy for cancer. World J Gastroenterol 2012;18:5106-13.

30. Theodoropoulos GE, Karantanos T, Stamopoulos P, Zografos G. Prospective evaluation of health-related quality of life after laparoscopic colectomy for cancer. Tech Coloproctol 2013;17:27-38. 
31. Bourke M. Current status of colonic endoscopic mucosal resection in the west and the interface with endoscopic submucosal dissection. Dig Endosc 2009;21(Supl. 1):S22-7.

32. Saito Y, Fukuzawa M, Matsuda T, Fukunaga S, Sakamoto T, Uraoka $\mathrm{T}$, et al. Clinical outcome of endoscopic submucosal dissection versus endoscopic mucosal resection of large colorectal tumors as determined by curative resection. Surg Endosc 2010;24:343-52.

33. Imagawa A, Okada H, Kawahara Y, Takenaka R, Kato J, Kawamoto $\mathrm{H}$, et al. Endoscopic submucosal dissection for early gastric cancer: results and degrees of technical difficulty as well as success. Endoscopy 2006;38:987-90.

34. Cabanes A, Pérez-Gómez B, Aragonés N, Pollán M, López-Abente G. La situación del cáncer en España, 1975-2006. Instituto de Salud Carlos III. Madrid; 2009.

35. Miguélez Ferreiro S, Cornide Santos M, Martínez Moreno E. Gastric cancer in a Spanish hospital: Segovia General Hospital (2005-2008). Gastroenterol Hepatol 2012;35:684-90.

36. Sugano K. Gastric cancer: Pathogenesis, screening, and treatment. Gastrointest Endosc Clin N Am 2008;18:513-22, ix.

37. Yamazato T, Oyama T, Yoshida T, Baba Y, Yamanouchi K, Ishii Y, et al. Two years' intensive training in endoscopic diagnosis facilitates detection of early gastric cancer. Intern Med 2012;51:1461-5.

38. Vila JJ, Uraoka T, Gómez Alonso M, Basterra M, Ishii H, Jiménez FJ, et al. Impacto del entrenamiento en un centro especializado en el índice diagnóstico de cáncer gástrico precoz y lesiones precancerosas gástricas en nuestro medio. Endoscopy 2012;44:A15.

39. Kakushima N, Fujishiro M, Kodashima S, Muraki Y, Tateishi A, Omata M. A learning curve for endoscopic submucosal dissection of gastric epithelial neoplasms. Endoscopy 2006;38:991-5.

40. Probst A, Pommer B, Golger D, Anthuber M, Arnholdt H, Messmann H. Endoscopic submucosal dissection in gastric neoplasia - experience from a European center. Endoscopy 2010;42:1037-44.

41. Uraoka T, Saito Y, Yahagi N. What are the latest developments in colorectal endoscopic submucosal dissection? World J Gastrointest Endosc 2012;4:296-300.

42. Sakurazawa N, Kato S, Fujita I, Kanazawa Y, Onodera H, Uchida E. Supportive techniques and devices for endoscopic submucosal dissection of gastric cancer. World J Gastrointest Endosc 2012;4:231-5.

43. Kiyotoki S, Nishikawa J, Satake M, Fukagawa Y, Shirai Y, Hamabe $\mathrm{K}$, et al. Usefulness of magnifying endoscopy with narrow-band imaging for determining gastric tumor margin. J Gastroenterol Hepatol 2010;25:1636-41.

44. Parra-Blanco A, Nicolas D, Arnau MR, Gimeno-Garcia AZ, Rodrigo L, Quintero E. Gastric endoscopic submucosal dissection assisted by a new traction method: The clip-band technique. A feasibility study in a porcine model (with video). Gastrointest Endosc 2011;74:1137-41.

45. Uraoka T, Kawahara Y, Ohara N, Kato J, Hori K, Okada H, et al. Carbon dioxide submucosal injection cushion: An innovative technique in endoscopic submucosal dissection. Dig Endosc 2011;23:5-9.

46. Uraoka T, Ishikawa S, Kato J, Higashi R, Suzuki H, Kaji E, et al. Advantages of using thin endoscope-assisted endoscopic submucosal dissection technique for large colorectal tumors. Dig Endosc 2010;22:186-91.

47. Vázquez-Sequeiros E, de Miquel DB, Olcina JR, Martín JA, García M, Lucas DJ, et al. Training model for teaching endoscopic submucosal dissection of gastric tumors. Rev Esp Enferm Dig 2009;101:546-52.

48. Fernández-Esparrach G, Matthes EL, Maurice D, Enderlé M, Thompson CC, Carr-Locke DL. A novel device for endoscopic submucosal dissection that combines water-jet submucosal hydrodissection and elevation with electrocautery: Initial experience in a porcine model. Gastrointest Endosc 2010;71:615-8.

49. Parra-Blanco A, Arnau MR, Nicolás-Pérez D, Gimeno-García AZ, González N, Díaz-Acosta JA, et al. Endoscopic submucosal dissection training with pig models in a Western country. World J Gastroenterol 2010;16:2895-900.

50. Marín-Gabriel JC, Hernán-Ocaña P, González-Blanco A, Díaz-Tasende J, Rodríguez-Muñoz S, Del Pozo-García A, et al. Disección submucosa endoscópica: fase inicial de la curva de aprendizaje. Evolución y Complicaciones. Endoscopy 2012;44:A14

51. Tanaka S, Oka S, Kaneko I, Hirata M, Mouri R, Kanao H, et al. Endoscopic submucosal dissection for colorectal neoplasia: Possibility of standardization. Gastrointest Endosc 2007;66:100-7.
52. Fujishiro M, Jung HY, Goda K, Hirasawa K, Kakushima N, Lee IL, et al. Desirable training and roles of Japanese endoscopists towards the further penetration of endoscopic submucosal dissection in Asia. Digestive Endoscopy 2012;24(Supl. 1):121-3.

53. Oda I, Odagaki T, Suzuki H, Nonaka S, Yoshinaga S. Learning curve for endoscopic submucosal dissection of early gastric cancer based on trainee experience. Digestive Endoscopy 2012;24(Supl. 1):129-32.

54. Yamamoto S, Uedo N, Ishihara R, Kajimoto N, Ogiyama H, Fukushima Y, et al. Endoscopic submucosal dissection for early gastric cancer performed by supervised residents: Assessment of feasibility and learning curve. Endoscopy 2009;41:923-8.

55. Deprez PH, Bergman JJ, Meisner S, Ponchon T, Repici A, Dinis-Ribeiro $\mathrm{M}$, et al. Current practice with endoscopic submucosal dissection in Europe: Position statement from a panel of experts. Endoscopy 2010;42:853-8.

56. Berr F, Ponchon T, Neureiter D, Kiesslich T, Haringsma J, Kaehler GF, et al. Experimental endoscopic submucosal dissection training in a porcine model: Learning experience of skilled Western endoscopists. Dig Endosc 2011;23:281-9.

57. Oyama T, Tomori A, Hotta K, Morita S, Kominato K, Tanaka M, et al. Endoscopic submucosal dissection of early esophageal cancer. Clin Gastroenterol Hepatol. 2005;3(Supl. 1):S67-70.

58. Fujishiro M, Yahagi N, Kakushima N, Kodashima S, Muraki Y, Ono S, et al. Endoscopic submucosal dissection of esophageal squamous cell neoplasms. Clin Gastroenterol Hepatol 2006;4:688-94.

59. Ishihara R, Iishi H, Uedo N, Takeuchi Y, Yamamoto S, Yamada T, et al. Comparison of EMR and endoscopic submucosal dissection for en bloc resection of early esophageal cancers in Japan. Gastrointest Endosc 2008;68:1066-72.

60. Ono S, Fujishiro M, Niimi K, Goto O, Kodashima S, Yamamichi N, et al. Long-term outcomes of endoscopic submucosal dissection for superficial esophageal squamous cell neoplasms. Gastrointest Endosc 2009;70:860-6.

61. Nonaka K, Arai S, Ishikawa K, Nakao M, Nakai Y, Togawa O, et al. Short term results of endoscopic submucosal dissection in superficial esophageal squamous cell neoplasms. World J Gastrointest Endosc 2010;2:69-74.

62. Takahashi H, Arimura Y, Masao H, Okahara S, Tanuma T, Kodaira J, et al Endoscopic submucosal dissection is superior to conventional endoscopic resection as a curative treatment for early squamous cell carcinoma of the esophagus (with video). Gastrointest Endosc 2010;72:255-64.

63. Repici A, Hassan C, Carlino A, Pagano N, Zullo A, Rando G, et al. Endoscopic submucosal dissection in patients with early esophageal squamous cell carcinoma: Results from a prospective Western series. Gastrointest Endosc 2010;71:715-21.

64. Ishii N, Horiki N, Itoh T, Uemura M, Maruyama M, Suzuki S, et al. Endoscopic submucosal dissection with a combination of small-caliber-tip transparent hood and flex knife is a safe and effective treatment for superficial esophageal neoplasias. Surg Endosc 2010;24:335-42.

65. Yamashina T, Ishihara R, Uedo N, Nagai K, Matsui F, Kawada N, et al. Safety and curative ability of endoscopic submucosal dissection for superficial esophageal cancers at least $50 \mathrm{~mm}$ in diameter. Dig Endosc 2012;24:220-5.

66. Yamamoto H. Endoscopic submucosal dissection--current success and future directions. Nat Rev Gastroenterol Hepatol 2012;9:519-29.

67. Toyonaga T, Man-I M, East JE, Nishino E, Ono W, Hirooka T, et al. 1,635 Endoscopic submucosal dissection cases in the esophagus, stomach, and colorectum: Complication rates and long-term outcomes. Surg Endosc 2013;27:1000-8.

68. Oka S, Tanaka S, Kaneko I, Mouri R, Hirata M, Kawamura T, et al. Advantage of endoscopic submucosal dissection compared with EMR for early gastric cancer. Gastrointest Endosc 2006;64:877-83.

69. Watanabe K, Ogata S, Kawazoe S, Watanabe K, Koyama T, Kajiwara T, et al. Clinical outcomes of EMR for gastric tumors: Historical pilot evaluation between endoscopic submucosal dissection and conventional mucosal resection. Gastrointest Endosc 2006;63:776-82.

70. Takenaka R, Kawahara Y, Okada H, Hori K, Inoue M, Kawano S, et al. Risk factors associated with local recurrence of early gastric cancers after endoscopic submucosal dissection. Gastrointest Endosc 2008;68:887-94.

71. Goto O, Fujishiro M, Kodashima S, Ono S, Omata M. Outcomes of endoscopic submucosal dissection for early gastric cancer with special reference to validation for curability criteria. Endoscopy 2009;41:118-22. 
72. Isomoto H, Shikuwa S, Yamaguchi N, Fukuda E, Ikeda K, Nishiyama $\mathrm{H}$, et al. Endoscopic submucosal dissection for early gastric cancer: a large-scale feasibility study. Gut 2009;58:331-6.

73. Nakamoto S, Sakai Y, Kasanuki J, Kondo F, Ooka Y, Kato K, et al. Indications for the use of endoscopic mucosal resection for early gastric cancer in Japan: A comparative study with endoscopic submucosal dissection. Endoscopy 2009;41:746-50.

74. Hotta K, Oyama T, Akamatsu T, Tomori A, Hasebe O, Nakamura N, et al. A comparison of outcomes of endoscopic submucosal dissection (ESD) for early gastric neoplasms between high-volume and low-volume centers: Multi-center retrospective questionnaire study conducted by the Nagano ESD Study Group. Intern Med. 2010;49:253-9.

75. Abe N, Gotoda T, Hirasawa T, Hoteya S, Ishido K, Ida Y, et al. Multicenter study of the long-term outcomes of endoscopic submucosal dissection for early gastric cancer in patients 80 years of age or older. Gastric Cancer 2012;15:70-5.

76. Akasaka T, Nishida T, Tsutsui S, Michida T, Yamada T, Ogiyama H, et al. Short-term outcomes of endoscopic submucosal dissection (ESD) for early gastric neoplasm: multicenter survey by osaka university ESD study group. Dig Endosc 2011;23:73-7.
77. Schumacher B, Charton JP, Nordmann T, Vieth M, Enderle M, Neuhaus H. Endoscopic submucosal dissection of early gastric neoplasia with a water jet-assisted knife: A Western, single-center experience. Gastrointest Endosc 2012;75:1166-74.

78. Niimi K, Fujishiro M, Kodashima S, Goto O, Ono S, Hirano K, et al Long-term outcomes of endoscopic submucosal dissection for colorectal epithelial neoplasms. Endoscopy 2010;42:723-9.

79. Nishiyama H, Isomoto H, Yamaguchi N, Fukuda E, Ikeda K, Ohnita $\mathrm{K}$, et al. Endoscopic submucosal dissection for colorectal epithelial neoplasms. Dis Colon Rectum 2010;53:161-8.

80. Saito Y, Uraoka T, Yamaguchi Y, Hotta K, Sakamoto N, Ikematsu $\mathrm{H}$, et al. A prospective, multicenter study of 1111 colorectal endoscopic submucosal dissections (with video). Gastrointest Endosc 2010;72:1217-25.

81. Yoshida N, Naito Y, Sakai K, Sumida Y, Kanemasa K, Inoue K, et al. Outcome of endoscopic submucosal dissection for colorectal tumors in elderly people. Int J Colorectal Dis 2010;25:455-61.

82. Uraoka T, Higashi R, Kato J, Kaji E, Suzuki H, Ishikawa S, et al Colorectal endoscopic submucosal dissection for elderly patients at least 80 years of age. Surg Endosc 2011;25:3000-7. 